\title{
Janusz Korczak, Aleksander Lewin and the Polish orphanage in Monetna in the Urals
}

Zarys treści: Artykuł omawia zesłańcze losy wybitnego polskiego pedagoga Aleksandra Lewina prowadzącego w okresie II wojny światowej polski sierociniec w osadzie Monietny w obwodzie swierdłowskim. Trafiały tam dzieci polskich rodzin wywiezionych przymusowo w głąb ZSRR w okresie sowieckiej okupacji wschodnich ziem II RP 1939-1941. Lewin, zajmując się nowymi teoriami wychowania, był powiązany z Januszem Korczakiem. W ZSRR próbował łączyć idee Korczaka z niezwykle popularnymi pomysłami Antona Makarenki.

Outline of content: The article discusses the fate while in exile of the eminent Polish pedagogue Aleksander Lewin, who during the World War II ran a Polish orphanage in the village of Monetna in the Sverdlovsk oblast. Children placed there came from Polish families forcibly deported deep into the USSR territories during the Soviet occupation of the Second Polish Republic in 1939-1941. Lewin was associated with Janusz Korczak while studying new theories of education. In the Soviet Union, he tried to combine Korczak's ideas with the extremely popular concepts of Anton Makarenko.

Słowa kluczowe: Polacy na zesłaniu w ZSRR, Aleksander Lewin, Janusz Korczak, dom dziecka w Monetnej, stosunki polsko-sowieckie w czasie II wojny światowej

Keywords: Poles in exile in the USSR, Aleksander Lewin, Janusz Korczak, the orphanage in Monetna, Soviet-Polish relations during World War II

Aleksander Lewin is a fascinating character, and through his academic publications and personal relations of the interwar period one permanently associated with Janusz Korczak. However, few people know of the period of his exile, when he ran the Polish orphanage in the village of Monetna near Sverdlovsk (USSR). It is where the outstanding Polish educator confronted, in extremely difficult conditions, the experiences from his work with Janusz Korczak with the pedagogical ideas of Anton Makarenko, popular in the USSR. 
Aleksander Lewin was born to a Jewish family. In the years 1937-1939 and 1946-1979, he worked in the Warsaw orphanage at 92 Krochmalna Street. It was here that he came into contact with Janusz Korczak's pedagogical ideas. After returning from exile in the Soviet Union, he co-created the Korczak Main Training and Educational Centre at Bartoszyce. He was also a long-time academic researcher at the Polish Teachers' Union Higher School of Education in Warsaw, and the author of a pedagogical methodology understood as a teaching subdiscipline, as well as a methodology of forming educational microsystems. A less glorious period of his career includes training educators and managing staff of the communist juvenile detention centre in Jaworzno, modelled after Soviet colonies for minors, for the purposes of the Ministry of State Security. Lewin, together with Bolesław Milewicz, tried to transplant the experiences of Anton Makarenko from the latter's work with demoralised youth in Soviet Russia of the 1930s. However, in the Polish reality, where those imprisoned were mainly young patriots arrested for actions targeting the communist government, this was a priori doomed to failure. ${ }^{1}$

However, let us move on to the period of Lewin's activities while in exile. The children's home in Monetna in the Sverdlovsk oblast, which he came to look after in 1944, became a haven for more than one hundred Polish orphans and half-orphans, displaced by World War II deep into the Soviet Union together with their families. The first Poles to arrive in the Sverdlovsk oblast were deported in the largest resettlement campaign of its kind on 10 February 1940. According to the NKVD, 2,809 families of Polish military settlers and foresters were forcibly resettled from Eastern lands of the Second Polish Republic incorporated into the USSR, and described in the Soviet historical terminology as Western Belarus and Western Ukraine. The decision that the oblast would be one of the main places of exile was made in Moscow in December 1939, at a special meeting of the Political Bureau of the All-Russian Communist Party (Bolsheviks), when it was ultimately decided that Polish military settlers and foresters would be sent into the depths of the Soviet Union. The destination of the forced deportations was not chosen by accident; the place was always in need of free hands to work on the extraction of peat required by the local industrial plants. Polish settler families were perfectly suited to such hard work. The NKVD held them in special settlements, often reminiscent of ordinary Soviet labour camps, supervising their slave labour for the benefit of the state, and collecting approximately 10 per cent of the profits they generated. In this way, the exiles did not only have to earn their livelihood, but also to "pay" the NKVD the costs of their imprisonment.

The second wave of exiles arrived in the oblast in the summer of 1940. On 21 June 1940, by virtue of the provisions of the Political Bureau of the All-Russian Communist Party (Bolsheviks), Polish citizens - war refugees residing in the

${ }^{1}$ Central Forced Labour Camp in Jaworzno, http://www.oboz.w.of.pl/mlodocianych.html (accessed: 10 July 2017). 
eastern territories of the Second Polish Republic annexed by the Soviet Union in the autumn of 1940, who due to the overpopulation in Polish cities in the annexed territories and their inability to confirm their identity were recognised by Soviet authorities as uncertain - were transported deep into the USSR. Most were Polish Jews from Central and Eastern Poland, fleeing the advancing German troops or expelled from their homes as a result of the first organised anti-Jewish actions. Tens of thousands of such people arrived in Bialystok and Lviv. Some were transported in the autumn of 1939 into Belarusian and Ukrainian SSRs, the rest deported. Aleksander Lewin was among the war refugees. Until the moment of their deportation, they camped in cities in extremely cramped conditions, deprived of livelihood and chances of finding work. Few returned to Warsaw after the start of the Soviet-German war, and their accounts of life under Soviet occupation were collected in the Ringelblum Archive. ${ }^{2}$

At the end of 1940, following three mass resettlement campaigns, Polish citizens (Poles, Jews, Ukrainians) of the Sverdlovsk oblast were located in the following districts: Pyshminsky ${ }^{3}$ (1,100 people), Tugulymsky (459) Serovsky (1,208), Isovsky (983) Verkhtavdinsky ${ }^{4}$ (800), Krasnouralsk (1,179), Kushvinsky (859), Revdinsky $(1,704)$, Novolyalinsky (702), Sukhoylozhsky (465), Toborinskiy ${ }^{5}$ (753), Berezovsky (1 037) Verkhotursky (209), Irbit $(1,274)$ and Rezhskiy $(944){ }^{6}$

Based on the reports of the NKVD military convoy, we can conclude that the exiles arrived here from the Vilnius, Nowogródek, Volhynian, Stanisławów, Ternopil, and Lviv Voivodeships.

All the exiles were categorised as special resettlers, which entailed certain legal consequences. Those resettled on the 10 February 1940 were assigned to the category of special resettlers and foresters (spetspereselentsy osadniki i lesniki), while those resettled in June 1940 - to the category of special resettlers-refugees (spetspereselentsy-bezhentsy). They lived in special settlements under the constant control of the NKVD, which "owned" the entire workforce. They were not allowed to leave their involuntary places of settlement without the consent of the commanders of the special settlements, forced to work in the locations designated by the NKVD in exchange for the so-called trudodni, and on this basis provided with food, usually of very poor quality. The living conditions of exiles in the special settlements in extreme cases resembled the living conditions in the Soviet labour camps. This resulted in a high mortality rate among young children and the elderly,

${ }^{2}$ Archiwum Ringelbluma, vol. 3: Relacje z Kresów, ed. A. Żbikowski, Warszawa, 2000.

${ }^{3}$ Pyshma - a river, a right tributary of the Tura. This is probably the Yushalinsky district.

${ }^{4}$ This is probably the Tavdinsky district.

5 This is probably the Turinsky district.

${ }^{6}$ A report by the head of the Department of Labour and Special Settlements of the NKVD, M. Konradov, of August 1941 on locating the special settlers, deportees and refugees in republics, countries and oblasts, I. Bilas, Represyvno-karal'na systema v Ukrayini 1917-1953. Suspil'no-politychnyy ta istoryko-pravovyy analiz, vol. 2, Kyyiv, 1994, pp. 196-199. 
and a very rapid exhaustion in the others. As most of the exiles were families with many young children, their situation grew increasingly desperate from month to month. Only after a certain time did people manage to acclimatise and identify ways to cheat at work, so that on paper the prohibitive norms were met, allowing for the necessary allocation of basic food products.

The situation of exiles only changed in August 1941 as a result of an amnesty announced under the Sikorski-Mayski agreement of 30 July 1941 between the Polish government in London and the Soviet authorities. According to the amnesty decree, the Poles and Jews deported into the Soviet Union and incarcerated in the forced labour camps received the freedom to travel and settle in places of their own choosing, as long as it was not contrary to the applicable law. Because of the very severe living conditions throughout the Sverdlovsk oblast, most of those who were staying there decided to leave their places of residence. It was not easy, as local authorities were not willing to let go of the labour force crucial to the strategic nature of the local factory production. Despite the pressures, intimidation attempts, and promises of improved living conditions, the exiles set out for the south of the USSR, to the locations were the Polish Army was forming. Among them were small groups of Polish Jews from the deportation of June 1940.

To those who stayed, the Embassy of the Republic of Poland in the USSR, created in the meantime, tried to provide the necessary assistance in all possible ways. One of the first tasks was to determine the number of people in need of care. At the end of 1942, there were a total of 7,599 deportees accounted for in the Sverdlovsk oblast: 2,251 men, 2,474 women, and 2,874 children. ${ }^{7}$ In terms of nationalities, $64 \%$ were Poles, $17 \%$ were Jews, while $19 \%$ were other Slavic minorities. ${ }^{8}$ It was a significant decrease, as at the time of appointing delegations and centres for trustees the number of exiles in the oblast was estimated at over 26,000. Most people had left at the first opportunity.

In the discussed year of 1942, according to the data of the trustees appointed to care for the exiles, they lived in the following districts: Alapaevsky (361 people), Pyshminsky (592), Tugulymsky (446), Achitsky (319), Serovsky (3,069), Garinsky (550), Isovsky (187), Verkhtavdinsky (739), Krasnouralsk (495), Kushvinsky (154), Revdinsky (2,347), Novolyalinsky (366), Sukholozhsky (352), Asbestovsky $(1,067)$, Toborinskiy (1,074), Berezovsky (485) and Ivdelsky (530). ${ }^{9}$

\footnotetext{
7 The number of Polish citizens reached by the trustee network of the Polish Embassy in the area. As on 1 February 1943, Hoover Institution, the Embassy team in Kuybyshev (HI AK), box 16, file 43, statistical overview of Polish Embassy trustees and the Polish population in the USSR, including nationality breakdown. As on 1 December 1942, Eastern Archive of the KARTA Centre in Warsaw (AW), copies of documents from the Hoover Institution on War, Revolution and Peace (HI), sign. V/HIAK/254, tab. 1.

8 The nationality breakdown of Polish citizens resettled to northern and central European Russia, HI AK, box 16, file 43, statistical overview of Polish Embassy trustees..., tab. 2.

9 A report by the head of the Department of Labour and Special Settlements of the NKVD, M. Konradov, of August 1941 on the number of men, women and children in the families of settlers and
} 
It is worth remembering that the first attempts to help Polish citizens in the USSR were taken by the Polish authorities in exile a long time before the outbreak of the Soviet-German war. One such action was led by the Polish Embassy in Tokyo. Based on correspondence with people living in the depths of the Soviet Union, it has been possible to determine the whereabouts of almost 9,000 people. Data on 835 people was collected from the Sverdlovsk oblast. ${ }^{10}$ Information on Poles staying in the oblast before the war was also reported by the bulletin of the Polish Red Cross Informator Wewnętrzny no. 12 of November $1940 .{ }^{11}$

The Sverdlovsk oblast was one of the first to have a delegation appointed, in August 1941, representing the interests of the Polish Embassy in the USSR. Unfortunately, it covered also the Chelyabinsk oblast, and it was in Chelyabinsk that its offices were located. In Sverdlovsk, however, an alimentation and sanitation point was created, as well as an independent military connection point. The oblast was a very important journey stage for those travelling from the north of the USSR to the south, for the places the army was forming, which did not favour developing structures of care over the local population.

At the start of his book about the children's home in Monetna, ${ }^{12}$ Lewin emphasises that the Polish Embassy of the London Government was not interested in helping the local Poles, which in fact was not the case. It is possible he wrote it due to the censorship within the Polish People's Republic. We should remember that from the very beginning the Polish Embassy in the USSR had enormous trouble in fulfilling the contracts concluded by the Polish and Soviet authorities. Although a Delegacy was appointed to assist the population of these areas, the delegate responsible for it, $\mathrm{W}$. Bruner, met strong resistance and lack of willingness to cooperate on the part of the local authorities from the very beginning, and in the second half of 1942 was expelled as persona non grata. Before it happened, he managed to establish several trustee institutions. The first operated in the Krasnouralsk district and was run by Józef Raszek and Henryk Schreiber, the other in the Revdensky district. It was managed by Alfred Jaworowski. ${ }^{13}$ In total, on 1 December 1942 fourteen trustees worked in the oblast (8 Poles and 5 Jews), which meant that one person had an average of 500 exiles under their care.

Until the breakdown of the Polish-Soviet relations in April 1943, the Polish embassy in the USSR was also able to establish a fragmentary care network.

refugees displaced from the USSR and BSSR, as on 1 April 1941, Bilas, Represyvno-karal'na systema, vol. 2, p. 195.

10 Zesłańcy polscy w ZSRR, Ambasada Rzeczypospolitej Polskiej w Japonii, Tokio, 1941.

11 Internal Bulletin of the Polish Red Cross, no. 11 of 31 October 1940, Historical Museum of the City of Kraków, PCK, no. 94.

12 A. Lewin, Problemy wychowania kolektywnego. Refleksje pedagogiczne na tle doświadczeń polskiego domu dziecka i szkoły na Uralu, Warszawa, 1953.

13 Report of the Social Welfare Department of the Polish Embassy in USSR for the period from 1 September to 15 December 1941, Hoover Institution on War, Revolution and Peace (HI), Polish Embassy in the USSR (AK), box 44, file 150, [pp.] 17-18. 
It included: a dispensary in the Krasnouralsk district, a sanitation point in the Pyshminsky district, two nurseries in the Berezovsky district, a nursery in Sosva, three nurseries, an orphanage, a home for the disabled and a supplementary alimentation point in the Krasnouralsk district, a sanitation point in Krasnoufimsk, an orphanage in Verkhnyaya Tura, two nurseries, two schools and a sanitation point in Pyshma and neighbouring area, six supplementary alimentation points in the Rezhskiy district, and a nursery in Revda. More than a thousand of the 7,000 people were taken under care in this way. This was a very strong result. Nurseries and orphanages helped families struggling to survive. It took some burden off the older family members, making it easier for them to find work and providing them with more nutrition, which in the situation of a permanent lack of even basic food products was the matter of life or death for the children lucky enough to be placed in a facility.

In Monetna, no such facility was established. It is not exactly clear why whether it was due to organisational difficulties, whether the trustees ran out of strength and energy, or whether it was simply decided that the existing facilities would take on the entire burden of care. It is worth remembering that the Sverdlovsk oblast was one of the smallest in terms of the number of Poles staying here, and so the Embassy and its employees necessarily focused their attentions more on areas where children were much more numerous, and living conditions even more unfavourable. This was the case in the Northern regions of the RSFSR and the southern republics, where tens of thousands of people on the brink of exhaustion arrived as a result of the formation of the Polish Army. Documents on the situation of Poles in the Sverdlovsk oblast are very fragmentary, and do not make the research easier. One of the reasons for this may be the aforementioned fact that the oblast was essentially a transit place for exiles from Komi ASSR, or from the Arkhangelsk oblast.

The aid for the exiles came from several sources. One of the most important ones was the food and second-hand clothing purchased by Polish authorities outside the USSR. A large part of this supply came from the USA and was delivered to the Soviet Union by sea to the active ports in the north and west of the empire, mainly Murmansk and Vladivostok. Some of the supplied goods were sent by sea to Persia and then overland in special convoys, transported to the Soviet Union and distributed by rail to the warehouses prepared by the Polish Embassy in Kuybyshev. From there, the aid was divided to the individual facilities, mainly through the trustee network. It was not much, but without this modest help many children would find themselves in an extreme living situation, directly threatening their lives, as with the outbreak of war the food allocations were considerably reduced. The second source of aid was the modest food allowances promised by the Soviet side, which found their way to Polish care facilities, schools, hospitals and homes for the disabled.

The exposure of the Katyn massacre became the perfect excuse for the Kremlin to break relations with the Polish government in London. This took place in April 
1943. Stalin no longer needed the "Polish card", as his primary goal - the help of the Allies in the early stages of the war - had been achieved. From the moment it was clear that the Soviet Union would not fall under the blows from the Wehrmacht, Kremlin's aim was to establish communist rule in the future Poland. For the care institutions run by the Polish Embassy in Kuybyshev, this was the last step towards their closure. Their problems had been piling up since the second half of 1942, when the Soviet authorities began to close down the Polish delegacy network. After the breakdown of Polish-Soviet relations and the announcement of a decree on compulsory passportization, which involved granting all exiles a compulsory Soviet citizenship, the Kremlin authorities took over the entire care network. Warehouses with aid and all educational establishments passed into the hands of local administration. A considerable part of them were closed, and children forcibly moved to Soviet children's homes; other were turned into Soviet facilities by introducing own management and principles, including Makarenko's educational theories. It was only the appointment of the Union of Polish Patriots by Joseph Stalin that changed somewhat the unfavourable situation of the Polish people. The Committee for Polish Children (Kompoldet) was set up to deal with the reorganisation of the care network, takeover of orphanages and children's homes that had not been closed down, and the creation of new ones. In August 1943 , the Union managed to recreate a small fraction of the care network with 35 care and educational centres and 2,611 pupils. It was a drop in the ocean, considering that just six months earlier there had been 500 different types of facilities, used by more than 27,000 people, including 192 children's homes with more than 12,000 children. $^{14}$

In such conditions, the Kompoldet proceeded to organise a children's home in Monetna in the Sverdlovsk oblast, on the ruins of an earlier care structure. Poles who worked there extracting peat for the huge metallurgical plant Uralmash Zavod were unable to take care of their children properly. Monetna was a large village near Sverdlovsk, and the seat of the Board of Peat Companies. The date of creating the children's home, 1 August 1944, indicates that it was not easy to organise such a facility. It was de facto created only after the appointment by the Kremlin of a puppet structure, the Polish Committee of National Liberation, and signing the "Polish-Soviet border agreement", in which it was decided to adopt the so-called Curzon Line as the basis of the border, which for most families in the oblast meant that their "little homeland" would forever remain on the side of the Soviet Union.

The children's home was in theory to help families working in peat extraction by relieving them of the duty to provide and care for their youngest children.

${ }^{14}$ Note of the People's Commissar of Internal Affairs of The USSR, L. Beria for J. Stalin about Poles in the territory of the USSR, as on 15 January 1943, Z archiwów sowieckich, vol. 3: Konflikty polsko-sowieckie 1942-1944, ed. W. Roszkowski, Warszawa, 1993, p. 41. 
It was also to start these children's education for their return to the home country. This involved typical propaganda work, designed to instil in them a love for the new, created somewhere far away, socialist homeland. However, the main task was to provide sufficient nutrition of the children directed to the home, and to start their school education, including teaching the Polish language. During the period of permanent war effort, when the Soviet Union used its last human and material resources to fight, this was no easy task. It was therefore truly fateful that it was Aleksander Lewin who received this challenging job, as is apparent from his recollections, which several previous managers could not cope with. A factor which adversely affected the situation at the facility was the resettlement of a large group of Poles from the Sverdlovsk oblast to Ukraine, combined with recruiting many of them into the ranks of the Polish Army troops, which were forming at the time. Many children only became orphans when their parents went to the front and died during the fighting.

When he first arrived at the children's home in Monetna, Aleksander Lewin had experienced both exile and work at an orphanage in Warsaw. It allowed him to look at the organisation of the facility from an entirely different perspective. When building, from the ground up, the mutual relations between his pupils, most of whom had traumatic experiences associated with their life in exile, he decided to use the experiences and ideas acquired while working with Janusz Korczak, enriching them with the educational concepts of Anton Makarenko. In the conditions he faced when creating a children's collective, a combination of the educational ideas of both pedagogues seemed the best solution. It is worth remembering that Makarenko had developed his pedagogical concepts in a completely different reality from Korczak's. The tasks given to children were also to serve a different aim. In the case of the children's home in Monetna, it turned out that on one hand it needed a children's self-government to build responsibility for oneself, the group, and the facility, and on the other - it needed a strong focus on the collective, which was able to control the difficult pupils, often demoralised by exile and war. Lewin's work clearly shows a battle between the ideas of Makarenko and Korczak to discover which ones were more effective when dealing with close to a hundred children, most of whom came in contact with the death of their close ones, hunger, and lack of any hope to improve their fate. Added to this were problems with mutual hostility on the grounds of nationality between Poles, Ukrainians and Jews, which had started before the war and in the first months of the occupation. It was intensified by exile, when everyone fought for their survival, and rather deep divisions in the period of the existence of the Polish Embassy in the USSR. The real test of the validity of the selected pedagogical methods was the appointment of a Children's Council and a Peer Court. It turned out, as evident from Lewin's recollections, that the idea of the court (as seen by Janusz Korczak) failed in Soviet reality. Only the Children's Council remained, whose activities "supported" the adult staff of the facility and its head. 
Lewin's increasingly efficient actions were interrupted in March 1945 when he was summoned to the front. Many other carers and teachers received the summons. The orphanage was going through difficult moments, as the staff left in place and the new management were unable to deal with the situation. As in many other centres, they were awaiting the information of when the first transports to the country were to leave. It was only the end of the war and Aleksander Lewin's return that allowed to restore the principles which had worked so effectively six months earlier. Despite great hopes, they all had to wait long months to travel to the country. Children and tutors left the Sverdlovsk oblast only in the second half of May 1946, and travelled to Poland with organised transport. The border was crossed on 12 June 1946; their destination was a special meeting point in Gostynin. There, children underwent a quarantine and were sent to various centres in the country. After handing over the children's home to the authorities, Aleksander Lewin returned to Warsaw, taking on another grand task: the reconstruction of the orphanage in Krochmalna. In his work he used both his pre-war experiences, and those acquired at the children's home in Monetna.

Comparing the situation in 39 children's homes run by the Union of Polish Patriots in the Soviet Union, based on accounts, memories and documents collected over the years, it is clear that at the time of Aleksander Lewin the facility in Monetna was outstanding in terms of educational activities and work with children. In many homes, the staff tried to provide children with food and a roof over their heads, however due to the lack of pedagogical training were unable to organise everyday life at the same level as Monetna. It did not seem to matter whether the conditions in a facility were better or worse. Most of the facilities were aiming to survive until such a time when it would be possible to return to the home country. One exception was the children's home in Zagorsk near Moscow, however it was also a special facility hosting the children of Polish communists, who carried out Kremlin's tasks. There, in turn, there was no question of implementing any of Korczak's ideas, as their educational model was based entirely on pedagogical recommendations of Makarenko.

\section{Bibliography}

\section{Studies}

Bilas I., Represyvno-karal'na systema v Ukrayini 1917-1953. Suspil'no-politychnyy ta istoryko-pravovyy analiz, vol. 2, Kyyiv, 1994.

Lewin A., Problemy wychowania kolektywnego. Refleksje pedagogiczne na tle doświadczeń polskiego domu dziecka i szkoły na Uralu, Warszawa, 1953. 


\section{Document collections}

Archiwum Ringelbluma, vol. 3: Relacje z Kresów, ed. A. Żbikowski, Warszawa, 2000.

$Z$ archiwów sowieckich, vol. 3: Konflikty polsko-sowieckie 1942-1944, ed. W. Roszkowski, Warszawa, 1993.

Zesłańcy polscy w ZSRR, Ambasada Rzeczypospolitej Polskiej w Japonii, Tokio, 1941.

Daniel Boćkowski, PhD, professor at the Department of History of Eastern Europe and Studies on the Empires of the 19th and 20th Centuries at the Institute of History of the Polish Academy of Sciences, Professor of the University of Bialystok, Head of the International Security Department at the Institute of History and Political Sciences at the University of Bialystok. Researcher into the history of the Soviet-Polish relations during World War II, contemporary threats to security and the Islamic world (MENA). His works include: Czas nadziei. Obywatele Rzeczypospolitej Polskiej w ZSRR i opieka nad nimi placówek polskich w latach 1940-1943 (Warszawa, 1999) and Na zawsze razem. Białostocczyzna i Łomżyńskie w polityce radzieckiej w czasie II wojny światowej (IX 1939 - VIII 1944) (Warszawa, 2005). Academic editor of the fourth volume of Niemcy w Polsce 1945-1950. Wybór dokumentów (Warszawa, 2001) (sdr@ihpan.edu.pl). 